\title{
Inclusão Escolar do Aluno Surdo na Percepção do Intérprete de Língua Brasileira de Sinais em Salas de Ciências e Biologia
}

\section{Deaf Students in Science and Biology Classes in The Perception of The Interpreter of Brazilian Sign Language}

\author{
Paulo César Gomes'; Tiago Fernando Alves de Moura²; Eduarda Gabriela Moura \\ Alves $^{3}$
}

1 Doutor em Educação para Ciência, UNESP, Botucatu, SP, Brasil - pc.gomes@unesp.br / https://orcid.org/0000-0003-24408097

2 Mestre em Educação para Ciência, UNESP, Bauru, SP, Brasil - ttiagomouraa@ yahoo.com.br / https://orcid.org/0000-00034963-5587

3 Bolsista CNPq Ensino Médio, Escola Estadual Américo Virgínio dos Santos/Secretaria Estadual de Educação - SP, Botucatu, SP, Brasil, duda.gabriela0@ gmail.com

\section{Recebido em Março/2019. Publicado em Agosto/2020}

Palavras-chave: Intérprete de LIBRAS. Inclusão Escolar. Educação do Surdo. Ensino de Ciências e Biologia.

\section{Keywords:}

Deaf Education.

Translator-interpreter of Brazilian Sign Language. Inclusive Education. Deaf Student. Science Education.
RESUMO: Nosso objetivo primordial neste trabalho foi investigar como os Intérpretes de Língua Brasileira de Sinais (LIBRAS) compreendem sua ação profissional na inclusão do surdo no contexto de aulas de Ciências e Biologia. Contudo, investigamos também o cumprimento do Decreto n. 5.626/2005, que trata da obrigatoriedade da inserção deste profissional nas escolas, em duas diferentes cidades do interior paulista, da região centro-oeste. Trata-se de uma Pesquisa Qualitativa em Educação na qual realizamos entrevistas semiestruturadas, análise documental e realizamos visitas a unidades escolares. Nossos resultados evidenciaram que em apenas uma das cidades existe a aplicação da Lei supra. Nesta, há apenas três escolas de Ensino Fundamental II e Ensino Médio que efetivamente recebem alunos surdos. As intérpretes participantes atuam nas escolas exclusivamente de acordo com a demanda de alunos surdos e não compreendem sua ação educativa nas aulas de ciências como atividade de ensino.

ABSTRACT: In this work, our primary objective was to investigate how the translator and interpreter of sign language (LIBRAS/Portuguese) (TILS) understand their professional action in the inclusion of the deaf in the context of Science and Biology classes. However, we also investigate the compliance of the Brazilian decree law number 5.626/2005, which deals with the compulsory insertion of this professional in Brazilian schools. In another way, the linguistic accessibility of deaf students who attend Middle School and High School, in two cities in São Paulo state interior, Brazil. This is a Qualitative Research in Education in which we conduct semi-structured interviews, documentary analysis and make visits to schools. Our results showed that in only one of the cities there is the application of the Law above. In this city, there are only three schools of Middle School and High School that effectively receive deaf students. The interpreters work in schools solely in accordance with the demand of deaf student's demands and do not understand their educational action in science classes as a teaching activity. 


\section{INTRODUÇÃO}

Nossos objetivos neste trabalho consistiram em (i) investigar a inclusão escolar do surdo especificamente acerca do cumprimento do Decreto $n^{\circ} 5.626 / 2005$, no que trata da inserção do intérprete de Língua Brasileira de Sinais, doravante, LIBRAS, em escolas públicas e, (ii) as percepções de intérpretes de LIBRAS sobre o ensino de ciências e biologia para o estudante surdo. O enfoque principal deste artigo consistiu num esforço para compreender o trabalho e mediação do intérprete de LIBRAS em contexto específico da educação do surdo na área das Ciências da Natureza.

No que tange a legislação que culminou no reconhecimento deste profissional, as autoras Silva e Oliveira (2016) destacaram: (1) a Resolução CNE/CEB no 2, de 11 de setembro de 2001, que instituiu Diretrizes Nacionais para a Educação Especial na Educação Básica e definiu normas para a atuação de professores-intérpretes de linguagens e códigos aplicáveis; (2) Lei $\mathrm{n}^{\circ} 10.436$ de 24/04/2002, que dispôs sobre a LIBRAS, reconhecendo-a como língua e meio legal de comunicação dos surdos; (3) Decreto no 5.626 de 22/12/2005 que regulamentou a Lei 10.436 de 2002 acerca do intérprete de LIBRAS e sua formação. E por fim, sustentam estas autoras (4) que "foi somente a partir da Lei $\mathrm{n}^{\mathrm{o}} 12.319$, de $1^{\mathrm{o}}$ de setembro de 2010, que a profissão de intérprete de Libras foi, enfim, regulamentada" (SILVA, OLIVEIRA, 2016, p.696), possibilitando a ocorrência de seleções e concursos públicos para o exercício do cargo de intérprete de LIBRAS em todo o país e que vinham ao encontro de distintos movimentos sociais na inclusão do surdo.

Incluir o surdo na sociedade ouvinte talvez seja uma das principais dificuldades no que cabe ao exercício fundamental da cidadania, aqui entendida como pleno exercício de direitos e deveres perante a sociedade e a nação, especialmente porque o "reconhecimento da diferença é o primeiro passo para a integração ${ }^{1}$ do surdo na comunidade ouvinte que o circula" (BRITO, 1993, p.45, grifos nossos). Contudo, é para além da integração que se pensa e concebe a inclusão do surdo nas escolas brasileiras. Aliás, Lacerda (2000) apontou o que se considera a idealização de uma escola inclusiva para o estudante surdo, isto é, trata-se de uma escola que foi planejada e organizada e especialmente pensada com o objetivo de ensinar pessoas surdas “[...] na qual todos os conteúdos acadêmicos fossem ministrados em sinais, por um professor com domínio de Libras, em meio a usuários de Libras, seria o ambiente acadêmico desejável para o desenvolvimento pleno da pessoa surda" (LACERDA, 2000, p.81).

${ }^{1}$ Para uma distinção dos conceitos de integração e inclusão ver, por exemplo, o texto de Aranha (2001). 
Segundo Camargo (2017, p.1), "o conceito de inclusão vem sendo amplamente e demasiadamente mal compreendido segundo a interpretação do senso comum. Esta crítica diz respeito ao fato de o mesmo ser 'aplicado' apenas aos estudantes, público-alvo da Educação Especial e ao contexto educacional". A crítica de Camargo (2017) estende-se a inclusão do surdo. Neste sentido, Carvalho (2005) afirma que: "para entender a educação inclusiva devese primeiro entender que a proposta não foi concebida apenas para determinados alunos e sim para todos, sem distinção. Entender que somos diferentes. Essa é nossa condição humana" (p.15, grifos nossos).

De acordo com Carvalho (2005), não basta apenas incluir o aluno, visto que ao "pé da letra", a inclusão entendida como inserção é o nível mais elementar do acolhimento entre pessoas. Aspecto em que se oferece apenas o espaço físico e não, necessariamente, as indispensáveis trocas simbólicas e afetivas entre as pessoas. É preciso integrar o aluno (implicando na reciprocidade das relações humanas) e conclui "na classe para que a aprendizagem aconteça, uma vez que integração deve andar junto com a inclusão um completando o outro" (CARVALHO, 2005). Entendemos que a ideia de integração deva passar gradativamente por um processo de superação (e incorporação) pelo movimento da inclusão real do estudante deficiente, que compreenda suas diferenças e especificidades.

Desde dezembro de 1996, a partir da publicação da Lei de Diretrizes e Bases da Educação Nacional 9.394, no panorama político e socioeducacional encontram-se problemáticas distintas referentes "a processos de inclusão/exclusão de pessoas com deficiência, também nomeadas, naquela época, como educandos portadores de necessidades especiais" (ORRÚ, 2017, p.13). Segundo esta autora estes processos estão fundamentados de modo restrito "no déficit, na doença, naquilo que falta ao indivíduo" (idem). A estigmatização do deficiente ocorre, segundo esta autora, a partir de critérios classificadores e rotuladores que promovem marginalização. Infelizmente, trata-se de processo residual e histórico da marginalização do deficiente e está também tem sido a realidade presente em muitas escolas brasileiras. Instituições que se expropriaram à responsabilidade da promoção da educação para todos, fundamentando suas justificativas em critérios ou parâmetros de diagnósticos que efetivamente separam o capaz do incapaz, quem é apto daqueles inaptos e, por fim, quem serão aqueles que serão capazes de adequar-se à realidade da escola, apesar de sua inabilidade ou limitação e acompanhar o ensinamento dos conteúdos numa sala de ensino regular. Assim, mesmo para este estudante é-lhe "atribuído um espaço à parte, onde a segregação se faz presente" (ORRU, 2016, p.11, grifos nossos). A autora continua afirmando: 
de seus alunos. [...]. Contudo, sob o prisma das práticas pedagógicas inovadoras e não excludentes, nos espaços de aprendizagem os aprendizes são concebidos como sujeitos aprendentes, com infindáveis possibilidades de aprendizagem, respeitandose sempre a heterogeneidade presente nos aprendizes e oportunizando possibilidades de transformações, de superações, de adaptações, e expectativas otimistas quanto ao aprendizado e desenvolvimento dos aprendizes (ORRU, 2016, p.214, grifos nossos).

No contexto da inclusão escolar do deficiente, o surdo possui especificidades e, ao negá-las ou ao não as reconhecer enquanto tal, negligenciam-se direitos e excluem-se pessoas. Nesta direção, em prol da integração do deficiente, salienta Silva Rosa: “É importante compreender que o sentido de integração social pressupõe a ampliação da participação [do surdo] nas situações comuns para indivíduos e grupos que se encontram segregados" (2003, p.235-6, grifos nossos). Integração que pode e deve caminhar para um processo de inclusão real e que não se restrinja ao ambiente escolar.

Um importante e fundamental papel na inclusão do surdo está presente em políticas públicas que zelam pela permanente presença do profissional intérprete de LIBRAS em salas de aulas e outros espaços não escolares. Contudo, este profissional foi tardiamente reconhecido no Brasil e sua atuação dá-se pelo processo de mediação linguística ou interpretação que ocorre entre os falantes da língua portuguesa oral e as pessoas surdas que dominam (ou que estão em processo de aprendizagem) a Língua Brasileira de Sinais (LIBRAS). Nesse ponto, é necessário discutir a relação entre o ofício de traduzir e interpretar, Lacerda (2015), afirma que:

\footnotetext{
Para alguns autores, os termos tradução e interpretação se complementam em certa medida, remetem a mesma tarefa: versar os conteúdos de uma dada língua para outra [...]. Outros autores defendem a ideia de que a tradução e a interpretação são conceitos que rementem a tarefas distintas. Traduzir estaria ligado à tarefa de versar de uma língua para outra trabalhando com textos escritos. Desse modo, o tradutor teria tempo para ler, para refletir sobre as palavras utilizadas os sentidos pretendidos [...]. Já interpretar está ligado à tarefa de versar de uma língua para outra nas relações interpessoais, trabalhando na simultaneidade, no curto espaço de tempo entre o ato de enunciar e o ato de dar acesso ao outro àquilo que foi enunciado (LACERDA, 2015, p.14, grifos nossos).
}

No sentido apontado por Lacerda (2015), o trabalho do intérprete não se trata de simples tradução como o faz o tradutor juramentado ao traduzir um documento da língua alemã para o português-brasileiro, trata-se, na verdade, de um processo de interpretação no qual o intérprete de LIBRAS faz modificações e inserções a medida que o assunto se insere num dado contexto da LIBRAS, enquanto língua espaço- visual. Logo, o intérprete é "o intermediário" ou aquele que faz os processos de mediação entre o falante e o surdo.

Lacerda (2010) apontou que o profissional que atua como intérprete de LIBRAS foi historicamente construído na informalidade, pela demanda da comunidade surda de forma a 
mediar a comunicação com os ouvintes. Destacou também que a maioria destes profissionais adquiriu fluência linguística em contextos religiosos e em seus grupos, de modo que se trata de comunidades solidárias ao bilinguismo dos surdos. Neste contexto "o intérprete molda-se às demandas da prática e vai constituindo-se como TILS ${ }^{2}$ nas e pelas experiências que vai vivenciando" (LACERDA, 2010, p. 137/8, grifos nossos). Na verdade, como Lacerda (2010) aponta, quando se trata de uma educação inclusiva bilíngue para surdos, as discussões sobre a atuação do intérprete de LIBRAS são ainda incipientes, já que pouco se sabe sobre os desdobramentos do que efetivamente ocorre na sala de aula. Aliás, vale destacar que,

'Os intérpretes existem desde a antigüidade, assim como os tradutores, com quem são freqüentemente confundidos; o tradutor trabalha com a palavra escrita, o intérprete com a palavra falada'. Assim começa o livreto da União Européia (Commission of the European Communitoes, s/d) com informações para os candidatos a seus cursos de formação de intérpretes que atende às necessidades da instituição, o maior empregador de tradutores e intérpretes do mundo (PAGURA, 2003, grifos nossos, aspas no original).

Pagura (2003) neste mesmo artigo discorreu sobre as principais modalidades de interpretação. Quais limitações existem na tradução dos conteúdos de ciências e biologia? Quais limitações ainda estão presentes na formação de professores desta área?

Segundo a pesquisadora Ronice Müller de Quadros (2006) a presença do intérprete de LIBRAS durante as aulas deve ser garantida na matrícula do surdo, contudo a presença deste profissional não é condição essencial ou fundamental para suprir adequadamente o que o aluno surdo precisa - barreira linguística não é a única limitação do surdo. A interpretação ocorre sempre a partir da língua portuguesa o que torna a LIBRAS secundarizada em todo o processo educativo na escola, contudo salienta, que a educação do surdo deveria ser feita prioritariamente em LIBRAS como primeira língua e a língua portuguesa como língua secundária (QUADROS, 2006). Segundo ela, a presença do intérprete de LIBRAS cria crenças limitantes para as aprendizagens do surdo, por exemplo, que a simples tradução/interpretação do conteúdo - pensado e organizado para os ouvintes - é condição adequada para a aprendizagem do surdo?

Quando se trata do Ensino de Biologia e Ciências, sabemos da existência de outros fatores limitantes e agravantes ao surdo no contexto real da sala de aula. Por exemplo, que a linguagem científica é carreada de conceitos que estão ligados intimamente entre si e, que a simples tradução do português-falado para LIBRAS não melhora ou tampouco garante que o surdo compreendeu (GOMES, BASSO, 2014; GOMES, FRIGERO, 2016).

2 TILS - Tradutor-intérprete de Língua Brasileira de Sinais - LIBRAS. 
Desta forma, entendemos que o trabalho do intérprete de LIBRAS nas aulas de ciências e biologia é contextualizado e situado. Depende não somente da compreensão linguística do surdo em relação aos sinais e classificadores aos quais ele será exposto durante a aula, mas também das estratégias de ensino utilizadas pelo professor titular, dos materiais de apoio escolhidos (vídeos, imagens, grafismos, esquemas etc.). Além disso, são imprescindíveis: a habilidade do intérprete de LIBRAS, outras ferramentas como softwares e grupo de apoio que serão suficientes para a compreensão do que o professor titular pretendeu ensinar. Desse modo, Lacerda (2015), alega que:

Tanto a tradução quanto a interpretação precisam ser realizadas por profissionais capazes de compreender e expressar ideias relacionadas às mais diferentes áreas de conhecimento humano, sem serem especialistas nessa área, [entretanto é] importante destacar que o bom domínio de um tema colabora para a atuação do tradutor/intérprete. Ele precisa conhecer e compreender o tema para fazer um bom trabalho, mas não necessariamente ser um profissional daquela área (LACERDA, 2015, p.16-17, grifos nossos).

Existem muitas maneiras de se ensinar um determinado conteúdo de Ciências ou Biologia na escola. O professor pode abordá-los de inúmeras maneiras: pode partir de uma notícia de jornal (escrito ou em vídeo), de um documentário, de um cartoon, de objetos trazidos pelos alunos ou pelo professor, a partir de uma atividade prática, etc. Contudo, quando se trata de ensinar ciências e biologia para um estudante surdo, "Há de se considerar que o intérprete, por ser ouvinte, pode 'colonizar' no momento da interpretação, remetendo o surdo à situação de submissão usual do passado, com o grupo hegemônico ouvinte administrando a identidade das pessoas surdas" (SILVA ROSA, 2003, p.242, grifos nossos). Salienta esta autora que a comunidade surda deve ter autonomia para selecionar qual informação é importante (e qual não é) - de forma a realizar por si mesma uma leitura do mundo e, que, suprimir ou adicionar informações pode manter o surdo marginalizado e sem o pleno exercício da cidadania.

Vale salientar que quando desprezadas as exigências de uma condição bilíngue e bicultural é previsível os prejuízos no desenvolvimento acadêmico, cognitivo do surdo e outros encaminhamentos como a não inserção e desvantagens nas relações sociais (SILVA et $a l, 2018)$. As autoras destacaram que: (1) as políticas de formação de profissionais para a inclusão do surdo precisam de mais atenção e discussões aprofundadas; (2) os maiores problemas de ordem pedagógica situam-se nas diferentes lacunas do conhecimento destes profissionais sobre a surdez, sobre o surdo e a LIBRAS e, fator que está diretamente proporcional a políticas públicas que valorizam ou não determinadas prioridades na formação 
de professores; (3) Há um abismo entre o que a legislação e diretrizes oficiais deliberam e o que efetivamente se faz em sala de aula na inclusão do surdo.

Apesar das dificuldades expostas na inclusão do surdo, há de se considerar que a profissão de Intérprete de Língua Brasileira de Sinais - LIBRAS ainda é recente. De acordo com Rodrigues e Valente (2011), o Brasil, assim como outros países,

Tem a formação de tradutores e intérpretes de línguas de sinais vinculada à prática de atividades voluntárias, que, com o decorrer do tempo e com o avanço das conquistas sociais do surdo, foram sendo valorizadas em sua condição de atividade trabalhista. Nesse sentido, a luta do surdo por espaços nas esferas sociais, como na educação, no trabalho, na saúde etc., e, principalmente, pelo reconhecimento de sua língua como língua de fato e da qual ele poderia se valer nos espaços sociais conquistados, deflagrou a necessidade pelo Tradutor e Intérprete de Língua de Sinais (RODRIGUES, VALENTE, 2011, p.15-16, grifos nossos).

Especificamente no sentido da regulamentação da profissão do intérprete de LIBRAS e outras legislações pode-se citar, por exemplo, a Lei de Acessibilidade n. ${ }^{\circ}$ 10.048/2000, Decreto n. 5.296 de 2004 (BRASIL, 2004) e Lei 10.436/2002, regulamentada pelo Decreto 5.626 (BRASIL, 2005). Lembrando que o Art. 14, $1^{\circ}$, inciso III do Decreto 5626/2005 garante e assegura o atendimento e escolaridade adequados ao estudante surdo quanto à formação do intérprete de LIBRAS, assegura:

Art. 17. A formação do tradutor e intérprete de LIBRAS - Língua Portuguesa deve efetivar-se por meio de curso superior de Tradução e Interpretação, com habilitação em LIBRAS - Língua Portuguesa.

Art. 18. Nos próximos dez anos, a partir da publicação deste Decreto, a formação de tradutor e intérprete de LIBRAS - Língua Portuguesa, em nível médio, deve ser realizada por meio de: I - cursos de educação profissional; II - cursos de extensão universitária; e III - cursos de formação continuada promovidos por instituições de ensino superior e instituições credenciadas por secretarias de educação.

Parágrafo único. A formação de tradutor e intérprete de LIBRAS pode ser realizada por organizações da sociedade civil representativas da comunidade surda, desde que o certificado seja convalidado por uma das instituições referidas no inciso III.

Art. 19. Nos próximos dez anos, a partir da publicação deste Decreto, caso não haja pessoas com a titulação exigida para o exercício da tradução e interpretação de LIBRAS - Língua Portuguesa, as instituições federais de ensino devem incluir, em seus quadros, profissionais com o seguinte perfil:

I - profissional ouvinte, de nível superior, com competência e fluência em LIBRAS para realizar a interpretação das duas línguas, de maneira simultânea e consecutiva, e com aprovação em exame de proficiência, promovido pelo Ministério da Educação, para atuação em instituições de ensino médio e de educação superior;

II - profissional ouvinte, de nível médio, com competência e fluência em LIBRAS para realizar a interpretação das duas línguas, de maneira simultânea e consecutiva, e com aprovação em exame de proficiência, promovido pelo Ministério da Educação, para atuação no ensino fundamental;

III - profissional surdo, com competência para realizar a interpretação de línguas de sinais de outros países para a LIBRAS, para atuação em cursos e eventos. Parágrafo único. As instituições privadas e as públicas dos sistemas de ensino federal, estadual, municipal e do Distrito Federal buscarão implementar as medidas referidas neste artigo como meio de assegurar aos alunos surdos ou com 
deficiência auditiva o acesso à comunicação, à informação e à educação (BRASIL, 2005, grifos nossos).

A legislação garante a presença do professor de LIBRAS ou instrutor de LIBRAS, tradutor e intérprete de LIBRAS - Língua Portuguesa. No que tange a formação do Intérprete de LIBRAS, ela deve necessariamente "efetivar-se por meio de curso superior de Tradução e Interpretação, com habilitação em LIBRAS - Língua Portuguesa" (Cf. Art. 17). Entretanto, na inexistência destes cursos, a certificação pode ocorrer mediante exame de proficiência realizado pelo MEC (Art.19). Segundo o decreto acima mencionado (BRASIL, 2005) a principal função/atribuição do intérprete de LIBRAS na sala de aula objetiva "viabilizar o acesso dos alunos aos conhecimentos e conteúdos curriculares, em todas as atividades didático-pedagógicas" (Art. 21, § 1. ${ }^{\circ}$, II). Apesar das garantias legais, há incertezas concretas em sua efetivação.

Antia e Kreimeyer (2001) destacaram a importância do papel do intérprete da língua de sinais no contexto norte-americano. Segundo estes autores, o intérprete atua de forma a avançar além da tradução/interpretação da língua falada para a língua de sinais. Neste contexto, ocorre o ensino de inúmeras habilidades, por exemplo, o desenvolvimento de capacidade de interpretação ou o desenvolvimento de habilidades interpessoais. Um exemplo disto ocorre quando o intérprete auxilia na interação entre estudantes surdos e ouvintes, em especial nos anos iniciais de escolarização. Neste sentido, “[...] é a informação do intérprete de LIBRAS sobres as dificuldades ou facilidades dos alunos surdos no processo de ensino/aprendizagem que norteia uma ação pedagógica mais adequada dos professores" (PIRES; NOBRE, 2004, grifos nossos).

A regulamentação da profissão de intérprete de LIBRAS é recente no Brasil, de acordo com Rodrigues e Valente (op.cit.), até o ano de 2010 não se tinha uma diretriz nacional sobre o perfil e as exigências para a formação profissional do Tradutor e Intérprete de Língua de Sinais. Esse quadro, contudo, foi alterado em julho de 2010, quando foi aprovado, pela Comissão de Assuntos Sociais do Senado (CAS), o projeto de lei que regulamentou a profissão de tradutor e intérprete da Língua Brasileira de Sinais (LIBRAS), assim, em 1. ${ }^{\circ}$ de setembro de 2010 ocorreu a promulgação da Lei Federal n 12.319 que estabeleceu as atribuições do tradutor e intérprete para o exercício de suas competências. Outro aspecto bem recente é o reconhecimento oficial pelo poder público da LIBRAS como meio legal de comunicação e expressão (cf. Lei Federal n 10.436, de 24 de abril de 2002). Aliás, esta mesma Lei define LIBRAS como “forma de comunicação e expressão, em que o sistema linguístico de natureza visual-motora, com estrutura gramatical própria, constituem 
um sistema linguístico de transmissão de ideias e fatos, oriundos de comunidades de pessoas surdas do Brasil” (BRASIL, 2002).

Diante do contexto acima apresentado, realizamos uma pesquisa qualitativa, na qual buscamos apresentar e identificar alguns aspectos referentes ao processo de inclusão das estudantes surdos em escolas públicas a partir da percepção do intérprete de LIBRAS e que apresentaremos a seguir.

\section{METODOLOGIA}

Realizamos nossas buscas em escolas de duas diferentes cidades ${ }^{3}$ do interior paulista (denominadas cidade A e cidade B do centro-oeste do estado), com até cento e cinquenta mil habitantes, especificamente no Ensino Fundamental II e no Ensino Médio. Trata-se de uma pesquisa exploratória, realizado por meio de uma pesquisa bibliográfica e também descritiva, onde se procura conhecer de forma aprofundada a temática a ser estudada. Como já mencionado, trata-se de uma Pesquisa Qualitativa em Educação (GIL, 2019; LÜDKE, ANDRÉ, 2013; STAKE, 2011), a qual pretende apresentar uma visão geral e aproximativa, a respeito de um determinado fato ou evento (GIL, 2019). A pesquisa proposta foi dividida em três etapas principais, a saber:

\section{ETAPA 1. Análise documental}

Nesta etapa foram investigadas, junto à Diretoria de Ensino e/ou Secretaria de Educação dos Municípios A e B, quais escolas efetivamente recebem os alunos surdos em turmas regulares e, quantas destas, possuem intérprete de LIBRAS e em qual período atuam. O objetivo foi mapear quantos profissionais existem na rede pública de ensino, locais onde estão distribuídos e quais turmas da Educação Básica eles estão atuando.

\section{ETAPA 2. Entrevistas semiestruturadas}

Nesta etapa, localizamos e convidamos três intérpretes de LIBRAS, todas do sexo feminino, que atuam em escolas públicas da cidade B para que participassem de uma entrevista, registrada em áudio para posterior análise e transcrição. O objetivo desta etapa foi conhecer como estes atores escolares compreendem o processo de inclusão escolar do aluno surdo em aulas de ciências e biologia. O roteiro de entrevista utilizado encontra-se ao final deste artigo.

\footnotetext{
${ }^{3}$ As duas cidades não serão identificadas, pois comprometeria o sigilo e anonimato das participantes nos termos das Resoluções 466/12 e 510/15 (CONEP). 


\section{ETAPA 3. Análise dos dados e aspectos éticos}

Os dados obtidos foram tabulados e categorizados. Para efetivar a análise dos dados, foi utilizada a Análise de Conteúdo, proposta por Bardin (2011). As entrevistas foram registradas com um gravador de áudio Sony ${ }^{\circledR}$ e transcritas. Após a transcrição, todos os arquivos foram destruídos. Procedeu-se a realização da etapa chamada "leitura flutuante" das entrevistas concedidas e procedemos a Análise de Conteúdo, propriamente dita, conforme proposto por Bardin (2011), esta se dividiu em: a) identificação temática das respostas e subdivisão em unidades; b) recortes de acordo com os conteúdos provenientes dos dados obtidos; e c) o agrupamento a categorização das unidades de respostas. Para esta autora, uma análise temática debruça-se sobre registros de crenças, atitudes, valores, motivações de opiniões, de tendências, etc., convertendo-os em "Unidade de Registro" na qual é o recorte de sentido quem dita a análise e não o recorte topográfico ou da sua forma. Assim, são os núcleos de sentido que permitem as análises e que compõem a comunicação. "Na verdade, o tema é a unidade de significação que se liberta naturalmente de um texto analisado segundo certos critérios relativos à teoria que serve de guia à leitura” (BARDIN, 2011, p.135).

Por fim, vale salientar que projeto foi submetido ao Comitê de Ética em Pesquisa da Faculdade de Medicina de Botucatu (CEP/FMB) e aprovado (protocolo CAAE 67430717.9.0000.5411). Todos os participantes assinaram um termo de consentimento livre e esclarecido (TCLE) na forma de convite informando o teor de sua participação no projeto de acordo com a Comissão Nacional de Ética em Pesquisa - CONEP (resoluções 466/12 e $510 / 15)$.

\section{RESULTADOS E DISCUSSÃO}

\section{ETAPA 1. Análise Documental}

A cidade A, segundo informa o site da Secretaria Estadual de Educação de São Paulo (Cf. http://www.educacao.sp.gov.br/central-de-atendimento/index_escolas.asp), conta com doze escolas entre públicas e particulares, inclusive Creches, escolas de Educação Infantil, Ensino Fundamental e Ensino Médio. A partir do contato com estas escolas, com a Diretoria de Ensino e com o Secretário Municipal de Educação da cidade A, constatamos que não existem intérpretes de LIBRAS atuando e não há nenhum aluno surdo incluído em salas de aulas regulares dentro do nosso recorte de análise na cidade A, isto é, escolas públicas de Ensino Fundamental II (do 6..$^{\circ}$ ao $9 .^{\circ}$ anos) e no Ensino Médio. Estes alunos surdos, se existem, estão todos institucionalizados. De fato, se estes alunos e alunas procuram matrícula 
nas escolas, como nos fora informado, eles são encaminhados a instituições como, por exemplo, a Associação Pais e Amigos dos Excepcionais (APAE) e outras entidades de assistência ao surdo, como já constatado anteriormente (GOMES, MINGUILI, 2014).

A cidade $\mathrm{B}$, também em consulta do mesmo endereço da internet, possui cento e dezenove instituições de ensino públicas e particulares, entre creches, escolas de Educação Infantil, Ensino Fundamental e Ensino Médio. Considerando o recorte de pesquisa acima mencionado, há apenas três escolas públicas que efetivamente recebem alunos surdos em turmas regulares - na perspectiva da inclusão escolar. Estas escolas que têm piso adaptado, corrimão sinalizado, elevadores, rampas, banheiros adaptados e até mesmo cuidadores. As escolas recebem pais, mães e responsáveis que queiram permanecer na escola durante todo o período que a pessoa com deficiência $(\mathrm{PcD})$ está no interior da escola, por exemplo, em aulas regulares, em atividades ao ar livre ou na sala de Atendimento Educacional Especializado (AEE) que ocorre no contraturno das aulas regulares. Consta que o atendimento escolar ao aluno surdo e aos demais alunos com deficiência está polarizado em apenas três das 16 escolas públicas que ofertam o Ensino Fundamental II e o Ensino Médio. Desta forma, caso um aluno com deficiência matricule-se numa das outras 13 escolas, ele é imediatamente informado que sua vaga estará disponível em uma das três que estão adaptadas para recebê-lo. A prefeitura local responsabiliza-se pela gratuidade no transporte e/ou deslocamento desses alunos até uma destas instituições de ensino. Assim, nossas entrevistas concentraram-se na cidade $\mathrm{B}$.

\section{ETAPA 2. Entrevistas semiestruturadas}

Nesta etapa, convidamos as quatro intérpretes de LIBRAS que localizamos na cidade B para que participassem desta pesquisa e colaborassem cedendo a entrevista em dia e local combinado antecipadamente. Apenas duas das intérpretes de LIBRAS concederam entrevistas. Uma delas recusou-se por motivos pessoais, segundo a diretora da escola, ela não participa das ATPC (aulas de trabalho pedagógico coletivo) da escola e à noite está ministra aulas em outra cidade. A outra, disse que não poderia porque acabara de exonerar o cargo de intérprete de LIBRAS na prefeitura municipal e que tinha sido aprovada em outro concurso público para professora da Educação Básica, no Ensino Fundamental I também no município B. Assim, como estava em processo de desligamento da escola atual, entrega de documentação e posse no novo cargo não faria a entrevista conosco. A seguir apresentaremos os dados obtidos, por participante. 
Ensino, Saúde e Ambiente - V13 (2), pp. 62-89, AG0.2020

\section{A INTÉRPRETE DE LIBRAS ALICE}

A primeira intérprete chama-se Alice (nome fictício), tem 45 anos de idade, é solteira e está há 9 anos no magistério. Trabalhou entre 2008 e 2010 na escola atual e retornou para a mesma em janeiro de 2017. Alice não completa a sua jornada de trabalho em outra escola e trabalha exclusivamente na escola atual durante 30 horas-aulas semanais. É formada em Letras (português-inglês) e cursou sua graduação numa faculdade particular no município B, concluindo o curso em 2007. Sobre a formação inicial, Alice considera adequada a formação que recebeu durante o período de graduação para atuar no ensino de língua portuguesa e língua inglesa.

Quando questionada se havia feito cursos de pós-graduação, Alice disse: "Eu comecei vários (risos) Mas, não terminei [nenhum]”. Ainda sobre a formação, ela disse que já fez diversos cursos, inclusive um de extensão universitária na área de LIBRAS. Os cursos de pós-graduação inconclusos foram todos na área da Educação Especial e sintetizou: "Gosto da Educação Especial. É um assunto que me interessa. Não só a LIBRAS, mas a dificuldade de aprendizagem e tal... Eu só não terminei mais porque acaba ficando caro, mas eu gosto” (intérprete Alice).

Alice relatou-nos também que trabalha com apenas um aluno surdo do $6 .^{\circ}$ ano de Ensino Fundamental. Disse que gosta bastante de atuar como intérprete de LIBRAS e complementou:

\footnotetext{
É o meu primeiro ano, e está sendo uma experiência nova [...] quando eu saí daqui [desta escola] e fui para [nome do distrito], eu me deparei com um aluno surdo. E eu queria muito me comunicar com ele. Só que ele também - ele não era... [pausa] Ele não tinha LIBRAS, era linguagem caseira. Então, assim, eu me interessei - quem me motivou aprender LIBRAS foi ter entrado em contato com esse aluno. Isso foi em 2011. Daí, eu comecei a me interessar (intérprete Alice, 45 anos).
}

As motivações pessoais de Alice têm relação também com sua formação na área da linguística e o contato inicial na profissão com o estudante surdo. Do relato, percebe-se que este aspecto foi central na tomada de decisão em tornar-se intérprete de LIBRAS. Os Quadros 1 e 2, abaixo, apresentam uma síntese da entrevista com a intérprete Alice. 
Ensino, Saúde e Ambiente - V13 (2), pp. 62-89, AG0.2020

Quadro 1. Síntese da entrevista com a intérprete de LIBRAS Alice - Parte 1

\begin{tabular}{|c|c|c|c|}
\hline Categoria & Subcategoria & $\begin{array}{l}\text { Unidade de } \\
\text { Registro }\end{array}$ & Unidade de Contexto \\
\hline \multirow{12}{*}{ 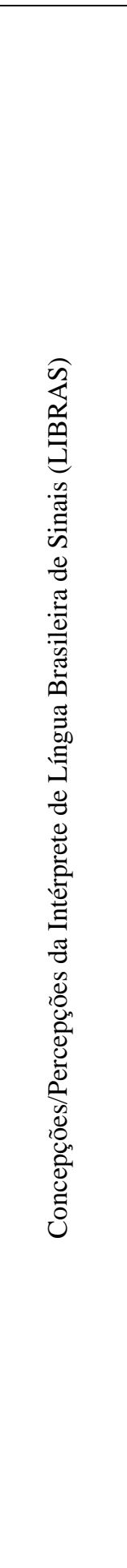 } & Inclusão Escolar & $\begin{array}{l}\text { Paradigma da } \\
\text { inclusão real }\end{array}$ & $\begin{array}{l}\text { Seria você inserir o aluno no contexto da aula. Ele } \\
\text { participar-ele conseguir participar. [...] não é só você } \\
\text { ter o aluno especial dentro da sala de aula. [...] É ele } \\
\text { fazer parte da discussão, de tudo. }\end{array}$ \\
\hline & \multirow[t]{2}{*}{$\begin{array}{l}\text { Inclusão Escolar } \\
\text { do Surdo }\end{array}$} & Para o surdo & $\begin{array}{l}\text { [...] é importante até para convívio dele na sociedade } \\
\text { [...] ele precisa disso. }\end{array}$ \\
\hline & & Para os outros & $\begin{array}{l}\text { [...] Não só o surdo [precisa da inclusão], mas os } \\
\text { outros alunos também. }\end{array}$ \\
\hline & \multirow[b]{2}{*}{$\begin{array}{l}\text { Sobre ser } \\
\text { intérprete de } \\
\text { LIBRAS }\end{array}$} & Para ela mesma & $\begin{array}{l}\text { Gosto. [Es]tá sendo um aprendizado muito grande, uma } \\
\text { lição de vida (risos). }\end{array}$ \\
\hline & & Para o surdo & $\begin{array}{l}\text { O Murilo [nome fictício do aluno surdo], apesar da } \\
\text { limitação dele - que ele não ouve - ele é uma criança } \\
\text { feliz? Ele é. Você escutou um gritinho agora? Foi dele. } \\
\text { Ele é um menino normal, é um menino brincalhão, feliz. } \\
\text { Mas, tem essa limitação. Eu falo que pra mim ele foi } \\
\text { um presente. }\end{array}$ \\
\hline & \multirow{7}{*}{$\begin{array}{l}\text { Inclusão do surdo } \\
\text { em aulas de } \\
\text { ciências e biologia }\end{array}$} & \multirow{3}{*}{$\begin{array}{c}\text { Sobre o } \\
\text { planejamento }\end{array}$} & $\begin{array}{l}\text { [...] as aulas são preparadas para os alunos ouvintes } e \\
\text { também são preparadas para o Murilo [surdo]. }\end{array}$ \\
\hline & & & $\begin{array}{l}\text { [...]Tá. Geralmente não é passado antecipadamente o } \\
\text { que vai ser ensinado. A professora vai dando a aula e } \\
\text { eu vou explicando [...] está explicando ali, eu estou } \\
\text { prestando atenção e eи vou passando pra ele. }\end{array}$ \\
\hline & & & $\begin{array}{l}\text { [...] Então ela já tem esse material [para uso com o } \\
\text { aluno surdo], ela já sabe como ela vai trazer a aula, } \\
\text { mas nunca fazemos um planejamento conjunto das } \\
\text { aulas. }\end{array}$ \\
\hline & & \multirow{2}{*}{$\begin{array}{c}\text { Sobre as ações } \\
\text { educativas da } \\
\text { professora regente } \\
\text { /Recursos } \\
\text { Materiais }\end{array}$} & $\begin{array}{l}\text { A professora traz coisas expositivas [visuais] pra ele } \\
\text { ver. [...] trago o meu computador, celular com internet. }\end{array}$ \\
\hline & & & $\begin{array}{l}\text { Então, eu sempre estou preocupada em mostrar figuras, } \\
\text { vídeos - para que ele possa entender o que a } \\
\text { professora [de ciências] está explicando [oralmente]. }\end{array}$ \\
\hline & & \multirow[t]{2}{*}{$\begin{array}{l}\text { Sobre as ações da } \\
\text { própria intérprete } \\
\text { de LIBRAS }\end{array}$} & $\begin{array}{l}\text { [...] A minha função não é ensinar - é transmitir o que } \\
\text { a professora está explicando. Então, a função de } \\
\text { ensinar é do professor regente da sala. Meu objetivo é } \\
\text { [...] transmitir o conteúdo e fazer com que ele entenda. }\end{array}$ \\
\hline & & & $\begin{array}{l}\text { [...] É como eu te falei - eu tenho que prestar atenção } \\
\text { no que a professora está falando para eu transmitir. }\end{array}$ \\
\hline
\end{tabular}

Alice relatou que, após a regulamentação recente da profissão do intérprete de LIBRAS, profissionalmente não percebeu nenhuma alteração no que se refere a questões trabalhistas diante dos outros profissionais da escola. Para Alice, a inclusão escolar do aluno com deficiência concretiza-se na sua efetiva atuação e participação na aula - não de forma 
individualizada, sobretudo na interação com as discussões coletivas com o professor e com os demais colegas. Desta feita, não basta que o aluno esteja presente em sala de aula, ele precisa estar integrado, implicando reciprocidade nas relações humanas (CARVALHO, 2005). Inclusão que não trata o surdo como estrangeiro e usuário de uma língua desconhecida (LACERDA, 2006), nas palavras desta autora "Ele é um estrangeiro que tem acesso aos conhecimentos de um modo diverso dos demais e se mantém isolado do grupo (ainda que existam contatos e um relacionamento amigável)" (idem, p.177).

É interessante perceber ainda que, em um primeiro momento, ao ser questionada sobre o processo de inclusão escolar, a interprete associou o processo de inclusão escolar a um todo e complexo processo que não se restringe aos estudantes com deficiência, isto é: “[...] Inclusão pra mim não é só você ter o aluno especial dentro da sala de aula. É você incluir esse aluno na aula, e ele participar... É ele fazer parte da discussão, de tudo" (intérprete Alice). Além disto, ao ser questionada sobre a inclusão do aluno com surdez nas aulas de ciências ela respondeu que a sala de aula é constituída, além dos alunos ditos "normais" por um aluno com deficiência auditiva (o surdo) e um aluno com deficiência visual e complementa: “Os dois são [inclusão]". Por outro lado, ao ser questionada sobre a inclusão do aluno surdo nas salas regulares, Alice expandiu seu conceito de inclusão escolar ao dizer: “[...] Ele precisa disso. Não só o surdo, mas os outros alunos também”. Percebemos, então, que o conceito de inclusão expresso por Alice neste contexto adquiriu novos contornos, pois, segundo ela, todos os alunos são beneficiados no processo de inclusão escolar. A nosso ver, Alice reconhece o paradigma da inclusão real, tal como proposto por Aranha (2001), Carvalho (2005), Camargo (2017) e por Carneiro (2015).

Apesar do exposto, percebemos as lacunas existentes entre o trabalho do professor de ciências e o da intérprete de LIBRAS. Apesar de alegar que as aulas são preparadas de forma inclusiva (para ouvintes e para o surdo) com muito material visual e vídeos, inexistem conversas ou planejamentos conjuntos sobre o que vai ser ensinado àquela turma. Alice toma conhecimento somente no momento em que o conteúdo está sendo explicado pela professora, "nunca fazemos um planejamento conjunto das aulas", um fator que pode sim agravar a inclusão real do surdo como mencionado por Lacerda (2010).

Os recursos disponibilizados por Alice possibilitam que o aluno surdo tenha acesso em tempo real a fotografias, vídeos, esquemas e figuras, com a finalidade de possibilitar entendimento do que o professor de ciências está explicando. Contudo, lembrou que a sua função ali não é ensinar um conteúdo de área, como as ciências naturais, que este papel é do professor. Seu papel como intérprete consiste em "transmitir o que a professora [de ciências] está explicando [e] fazer com que ele [o surdo] entenda" (intérprete Alice). Este 
aspecto da fala de Alice contraria o que a literatura traz sobre o papel do intérprete de LIBRAS em salas inclusivas em relação ao surdo e sua turma (LACERDA, POLETTI, 2004).

Quadro 2. Síntese da entrevista com a intérprete de LIBRAS Alice - Parte 2

\begin{tabular}{|c|c|c|c|}
\hline Categoria & Subcategoria & $\begin{array}{l}\text { Unidade de } \\
\text { Registro }\end{array}$ & Unidade de Contexto \\
\hline \multirow{10}{*}{ 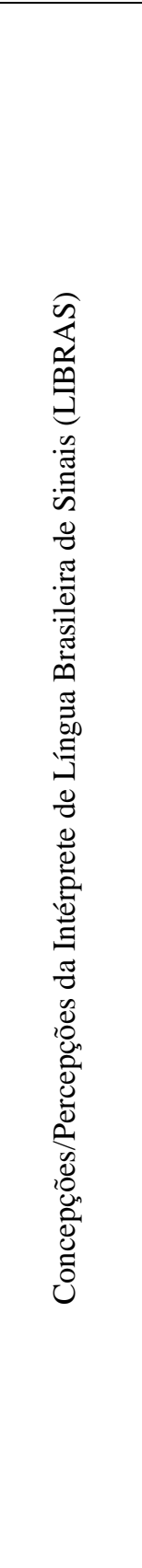 } & \multirow{8}{*}{$\begin{array}{l}\text { Sobre ensinar } \\
\text { ciências para o } \\
\text { surdo }\end{array}$} & \multirow[b]{4}{*}{ Obstáculos } & $\begin{array}{l}\text { E, na ausência de algum sinal é uma dificuldade e tem que } \\
\text { correr atrás [...] às vezes, são alguns sinais que não se usa } \\
\text { diariamente, então precisa procurar. }\end{array}$ \\
\hline & & & $\begin{array}{l}\text { [...] o meu aluno não utiliza muito as LIBRAS - ele utiliza } \\
\text { mais a linguagem caseira. Então isso dificulta um pouco a } \\
\text { comunicação [...] o que tem sido obstáculo é a necessidade } \\
\text { de precisar de mais material. }\end{array}$ \\
\hline & & & $\begin{array}{l}\text { Eu precisaria de uma internet [Wi-Fi] funcionando até a } \\
\text { sala - pra poder procurar. Ela [a rede de internet] estava } \\
\text { funcionando, mas deu problema e isso atrapalha. }\end{array}$ \\
\hline & & & $\begin{array}{l}\text { [...] para conseguir acessar imagens pelo computador. Eu } \\
\text { não consigo ter um sinal de internet, eu uso o meu celular. } \\
\text { [...] Procura em livro, aplicativos. Uso os recursos que } \\
\text { temos a mão. }\end{array}$ \\
\hline & & $\begin{array}{l}\text { Investigar o que } \\
\text { o surdo já sabe }\end{array}$ & $\begin{array}{l}\text { Então... [estes conhecimentos não influenciam o trabalho } \\
\text { da intérprete] Não. A professora dá a matéria, e eu } \\
\text { transmito no tempo dele. }\end{array}$ \\
\hline & & \multirow[t]{2}{*}{ Facilitadores } & $\begin{array}{l}\text { Essa contextualização foi o que eu falei. É... Às vezes eu não } \\
\text { sei algum sinal, e daí tenho que procurar. E muito trabalho } \\
\text { visual. Muito o visual para ele. }\end{array}$ \\
\hline & & & $\begin{array}{l}\text { [...] O professor deveria elaborar as aulas de ciências } \\
\text { [pensando no aspecto visual]. Quer dizer, a gente "bate" } \\
\text { muito na questão do visual. O surdo precisa disso, do visual, } \\
\text { vídeos, imagens. }\end{array}$ \\
\hline & & $\begin{array}{l}\text { Rede } \\
\text { "informal" de } \\
\text { Apoio }\end{array}$ & $\begin{array}{l}\text { Na ausência de um sinal? Eu pesquiso. Daí se não tiver esse } \\
\text { sinal - é, eu também participo muito de grupos no } \\
\text { (aplicativo) WhatsApp de intérpretes. Às vezes, eu não } \\
\text { conheço um sinal e eu coloco lá. Ou, alguém grava um vídeo } \\
\text { e me manda, ou manda uma figura. Mas, eu tenho levado na } \\
\text { sala - eu uso bastante dicionários. E, aplicativo no celular } \\
{[\ldots]}\end{array}$ \\
\hline & \multirow{2}{*}{$\begin{array}{l}\text { Sobre avaliar } \mathrm{o} \\
\text { surdo } \quad \text { em } \\
\text { ciências }\end{array}$} & $\begin{array}{l}\text { Mensurar a } \\
\text { aprendizagem }\end{array}$ & $\begin{array}{l}\text { Ah... Ele aprende! [Ele aprendeu se consegue fazer a prova } \\
\text { escrita]. Os resultados dele em provas. }\end{array}$ \\
\hline & & $\begin{array}{l}\text { Experiências } \\
\text { anteriores }\end{array}$ & $\begin{array}{l}\text { A professora de ciências me auxilia. Ela prepara a aula e } \\
\text { ela já tem uma experiência anterior com aluno surdo. }\end{array}$ \\
\hline
\end{tabular}

Alice salientou ainda dificuldades como a falta de rede wi-fi (às vezes, cai a rede) atrapalha bastante a aula, no sentido de limitar a apresentação do conteúdo e a compreensão do aluno exclusivamente a LIBRAS. Outra dificuldade é a falta do domínio da LIBRAS por parte do surdo e o uso da "linguagem caseira", ou seja, sinais ou classificadores de uso restrito e não partilhados pela comunidade surda. Além dos problemas mencionados (improviso, falta 
de material e equipamentos), há problemas linguísticos: (a) ausência de sinais e classificadores para alguns conceitos científicos; (b) falta de hábito no uso "coloquial" ou cotidiano de sinais e classificadores para conceitos científicos em LIBRAS e; (c) até desconhecimentos de sinais já existentes pelo surdo e pelo intérprete de LIBRAS.

Retomando, Alice ressaltou ainda que "não ensina", apenas "transmite o conteúdo" ministrado pela professora regente, de modo a "fazer com que ele [o surdo] entenda", podemos perceber que essa concepção de Alice "sobre não ensinar" vai contra o que é afirmado por Antia e Kreimeyer (2001), ou seja, que o intérprete possui uma função que vai além da mera tradução, transmitindo aos alunos diversas habilidades. Ao dominar o conteúdo que será ministrado o intérprete de LIBRAS pode e deve escolher a melhor maneira de transmitir esse conteúdo, fazendo as modificações e alterações necessárias para que o aluno consiga compreender o tema ministrado, por esse motivo Lacerda (2015) afirma que ao conhecer o tema que será trabalhado o intérprete está garantindo um bom trabalho. Entretanto da fala de Alice, percebe-se que não existe - como mencionado, qualquer entrosamento entre o trabalho da professora de ciências e o trabalho da intérprete "não é passado antecipadamente o que vai ser ensinado", assim, o trabalho da intérprete com o aluno surdo em aulas de ciências funciona - no que poderíamos chamar de um constante improviso.

Alice não considera importante saber os "conhecimentos prévios" do estudante surdo, porque estes saberes do surdo não influenciarão em nada no seu trabalho de interpretação (e de ensino) do conteúdo de ciências. Porém, ao negar os conhecimentos prévios do aluno surdo, ao negar-se conhecer sua interpretação sobre o mundo, tratando-o como uma tábula rasa, uma folha em branco, estamos colocando esse aluno, assim como argumenta Silva Rosa (2003), em uma situação de total submissão e passividade, favorecendo assim sua colonização. Ignorar tais conhecimentos também é desprezar os avanços recentes de pesquisas na área de Ensino de Ciências, para mencionar algumas destas, Carvalho (2013), Trivelato e Silva (2011) e Pozo e Crespo (2009).

A intérprete mencionou que faz uso de softwares e da rede de computadores (internet) para a busca de vídeos e imagens que possam contribuir com a contextualização do conteúdo de ciências. A professora de ciências ajuda quando ele prepara uma aula "mais visual", porque "ela já tem uma experiência anterior com o aluno surdo". Acreditamos que o trabalho do intérprete de LIBRAS e sua presença nas aulas de ciências é importante e, talvez, fundamental. Contudo, este aspecto não garante a aprendizagem dos conteúdos escolares de ciências pelo estudante surdo - condição que está sujeita a inúmeras variáveis que ultrapassam a barreira linguística. A ideia de que todos os alunos aprendam LIBRAS deveria ser considerada e mesmo a contratação de um professor surdo em período integral. A proposta 
de escolas inclusivas exige exclusividade dos profissionais, de modo a considerar períodos livres para planejamento conjunto, preparo e correção de atividades, elaboração de material didático, entre outros.

\section{A INTÉRPRETE DE LIBRAS MARIA}

Na entrevista, Maria (nome fictício) informou-nos que vive em união estável com um surdo. Está há 6 anos no magistério e há 4 anos na escola atual. Não trabalha em outra escola e tem jornada de 7 horas-aulas de jornada diária. É graduada em Letras por uma faculdade particular, sendo que concluiu o curso em 2002. Relatou-nos que nunca cursou pósgraduação, nem latu senso. Disse-nos ainda que realiza outra atividade profissional, na qual dá aulas para alunos surdos na Igreja, na área de catequese. Este relato é coerente com a formação inicial do intérprete de LIBRAS nos contextos religiosos (LACERDA, 2010).

Maria disse que adora atuar como interprete de LIBRAS, "porque eles são sinceros e tem vontade de aprender, e fico feliz que posso levar a educação para eles, porque sem o intérprete eles não conseguem aprender quase nada" (Maria). A fala de Maria idealiza o surdo e o papel do intérprete de LIBRAS. Devemos analisar a frase de Maria "sem o intérprete eles não conseguem aprender quase nada" com certo cuidado. Aparentemente, através desta frase, ela tem como objetivo deixar evidente que o papel do intérprete é fundamental no processo de ensino e aprendizagem do aluno surdo. Por outro lado, essa frase pode demonstrar certo conformismo com as capacidades dos alunos, que são tidos frequentemente como incapazes de aprender em função de sua deficiência. Ela nos disse ainda que a graduação e o curso preparatório de LIBRAS não a prepararam adequadamente para atuar como professora/intérprete de LIBRAS e que "Aprendi muita coisa com a prática, porque meu marido é surdo, então como namorava com ele antes da minha graduação eu já sabia muita coisa, mas é claro que a faculdade ajudou” (intérprete Maria). Os quadros seguintes sintetizam a entrevista. 
Quadro 3. Síntese da entrevista com a intérprete de LIBRAS Maria - Parte 1

\begin{tabular}{|c|c|c|c|}
\hline Categoria & Subcategoria & $\begin{array}{l}\text { Unidade de } \\
\text { Registro }\end{array}$ & Unidade de Contexto \\
\hline \multirow{21}{*}{ 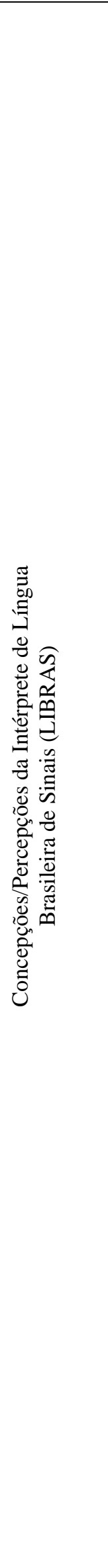 } & Inclusão Escolar & $\begin{array}{l}\text { Paradigma da } \\
\text { normatização }\end{array}$ & $\begin{array}{l}\text { [...] serem tratados como qualquer outra pessoa sem } \\
\text { problema nenhum. [...] como qualquer outro aluno. }\end{array}$ \\
\hline & \multirow{6}{*}{$\begin{array}{l}\text { Inclusão Escolar } \\
\text { do Surdo }\end{array}$} & \multirow{3}{*}{ Para o surdo } & [...] eles têm muita dificuldade na língua portuguesa. \\
\hline & & & $\begin{array}{l}\text { [...] para a [língua] escrita fazer sentido, eles têm que } \\
\text { ouvir [ver a LIBRAS, na verdade]. Não é impossível, mas é } \\
\text { complicado. }\end{array}$ \\
\hline & & & $\begin{array}{l}\text { O que eles precisam é ter o domínio da língua [LIBRAS]. } \\
\text { [...] precisam muito de recurso visual para entender as } \\
\text { coisas. }\end{array}$ \\
\hline & & $\begin{array}{l}\text { Para a intérprete } \\
\text { de LIBRAS }\end{array}$ & $\begin{array}{l}\text { Eu estando aqui já é um meio de inclusão, eu sou apenas } \\
\text { uma ponte entre eles e o resto do mundo. }\end{array}$ \\
\hline & & \multirow[t]{2}{*}{ Para os outros } & $\begin{array}{l}\text { [...] mas os alunos, funcionários se colocam à disposição } \\
\text { para incluir eles. }\end{array}$ \\
\hline & & & $\begin{array}{l}\text { [...] onde os funcionários, coleguinhas e professores } \\
\text { aprendam a linguagem deles e entendam a realidade deles. }\end{array}$ \\
\hline & \multirow{3}{*}{$\begin{array}{l}\text { Sobre ser } \\
\text { intérprete de } \\
\text { LIBRAS }\end{array}$} & \multirow[t]{2}{*}{$\begin{array}{l}\text { Para ela mesma/ } \\
\text { História pessoal }\end{array}$} & $\begin{array}{l}\text { Adoro exercer essa profissão, não é apenas por dinheiro. } \\
\text { Meu marido é surdo, e vivo nessa comunidade há muitos } \\
\text { anos. }\end{array}$ \\
\hline & & & $\begin{array}{l}\text { [...] estudei muito isso para me preparar para este } \\
\text { trabalho. }\end{array}$ \\
\hline & & $\begin{array}{l}\text { Questões } \\
\text { administrativas }\end{array}$ & $\begin{array}{l}\text { São poucos surdos [...] a demanda de intérprete de LIBRAS } \\
e ́ \text { de acordo com o número de surdos. Alguns são } \\
\text { concursados e outros contratados conforme a demanda. }\end{array}$ \\
\hline & \multirow{11}{*}{$\begin{array}{l}\text { Inclusão do } \\
\text { surdo em aulas } \\
\text { de ciências e } \\
\text { biologia }\end{array}$} & \multirow{4}{*}{$\begin{array}{l}\text { Sobre as ações } \\
\text { educativas da } \\
\text { professora } \\
\text { regente }\end{array}$} & $\begin{array}{l}\text { O professor ele dá a aula normal, igual para todos, às } \\
\text { vezes, eles sentem a necessidade de explicar de um jeito } \\
\text { diferente para o aluno surdo. }\end{array}$ \\
\hline & & & $\begin{array}{l}\text { Ele [o professor de ciências] auxilia demais, adapta a } \\
\text { prova, A matéria de ciências tem muito sentido para eles } \\
\text { [...] são muito bons, tem muita facilidade. }\end{array}$ \\
\hline & & & $\begin{array}{l}\text { [...] O conteúdo que professor vai ensinar ele, às vezes, } \\
\text { avisa antes ou então vejo no livro qual será o próximo } \\
\text { conteúdo, e então pesquiso antes, procuro na internet o } \\
\text { conteúdo, caso eu veja que tenho alguma dificuldade. }\end{array}$ \\
\hline & & & $\begin{array}{l}\text { É que geralmente o professor tem muita aula para dar, em } \\
\text { escolas diferentes, e sentar e programar o conteúdo é } \\
\text { muito difícil, porém nos comunicarmos de alguma forma } \\
\text { [...] tem a prova que é adaptada, a questão visual, mostra } \\
\text { vídeos e tudo mais. }\end{array}$ \\
\hline & & $\begin{array}{l}\text { Sobre as ações } \\
\text { da própria } \\
\text { intérprete de } \\
\text { LIBRAS }\end{array}$ & $\begin{array}{l}\text { [o professor de ciências explica] E então, eu paro e vou } \\
\text { traduzindo tudo que eles vão falando. E então, vou } \\
\text { mediando. Quando o professor faz isso [fala de modo } \\
\text { diferente para o surdo] é um meio de incluir o aluno. }\end{array}$ \\
\hline & & \multirow[t]{2}{*}{$\begin{array}{l}\text { Recursos } \\
\text { Materiais }\end{array}$} & $\begin{array}{l}\text { [Os professores] trazem muitos recursos visuais, e isso é } \\
\text { importante. }\end{array}$ \\
\hline & & & $\begin{array}{l}\text { Eu tenho [...] livro em LIBRAS que às vezes eu uso [...] } \\
\text { Não preciso [de notebook] [...] O material é mais voltado } \\
\text { para eles, porque nós já viemos preparadas. }\end{array}$ \\
\hline & & \multirow[t]{3}{*}{$\begin{array}{l}\text { Condição do } \\
\text { Aluno surdo/ } \\
\text { Obstáculos }\end{array}$} & $\begin{array}{l}\text { E se eles [os surdos] têm uma necessidade diferenciada } \\
\text { nós conversamos com os professores, coordenadores, e eles } \\
\text { adaptam [...] }\end{array}$ \\
\hline & & & $\begin{array}{l}\text { Eles não sabem todos os sinais. Eles vêm para o ensino } \\
\text { regular, a maioria sem a alfabetização na LIBRAS. Porque } \\
\text { os pais são ouvintes, mas eles sempre serão surdos. }\end{array}$ \\
\hline & & & $\begin{array}{l}\text { Ele [o surdo] vem sem nenhuma fluência na língua e sem } \\
\text { alfabetização }\end{array}$ \\
\hline & & Bilinguismo & [...] precisam mesmo é de uma escola específica que tenha \\
\hline
\end{tabular}




\begin{tabular}{|l|l|l|}
\hline & $\begin{array}{l}\text { um professor surdo para trabalhar com eles ou uma } \\
\text { professora de português ouvinte. }\end{array}$ \\
\hline
\end{tabular}

A intérprete Maria relatou-nos que atualmente possui dois estudantes surdos matriculados no 9..$^{\circ}$ ano do Ensino Fundamental. Os intérpretes de LIBRAS são contratados de acordo com a demanda de alunos surdos - alguns "são concursados, são fixos da prefeitura, e outros são contratados para atender a demanda". Quando questionada a respeito da inclusão escolar, associou o processo como sendo a inserção do aluno com deficiência na escola, onde esse, deveria ser tratado como qualquer outra pessoa, em suas palavras: "[...] sem problema nenhum", comparando-o desse modo com os estudantes ditos "normais". Essa concepção de normalidade/anormalidade, aparentemente é uma concepção que ainda está muito arraigada em nossa sociedade, que caminha na direção oposta ao que é defendido por Carvalho (2005).

Sendo assim, para Maria, a inclusão escolar do deficiente refere-se à não marginalização e à igualdade no tratamento dado por toda a comunidade escolar a estes estudantes. Ela acredita que o papel da intérprete na inclusão do surdo é basilar, trata-se de uma ponte entre os surdos e o restante do mundo. Para ela, na condição de esposa de um surdo, reconhece que a escola é importante, mas que os surdos precisariam mesmo de "uma escola específica que tenha um professor surdo para trabalhar com eles". Ela destacou ainda, que o principal problema (dificuldade) do aluno com surdez é a língua portuguesa.

Maria sinalizou a importância de o professor de ciências parar a aula e, segundo a mesma, dar uma atenção especial e individualizada ao aluno surdo "é um meio de incluir o aluno [surdo]". Dois problemas são centrais enquanto objetivos para as aprendizagens dos surdos: eles precisam aprender LIBRAS e aprender o conteúdo de área de cada disciplina (LACERDA, 2015; LACERDA, 2006; LACERDA, POLETTI, 2006). Tudo isso ocorre simultaneamente. Maria salientou que seus alunos são analfabetos em LIBRAS e, em geral, filhos de pai e mãe ouvintes que não sabem LIBRAS. Assim, sintetiza:

Os alunos vêm desestruturados. Então, eles vêm analfabetos em LIBRAS e, logo em português. A estrutura familiar é essencial, e então fica complicado se a família não é assim [usuária da LIBRAS]. Porque além de termos que interpretar as aulas, nós temos que ensinar os sinais, seria muito importante ter um instrutor surdo, pois ai eles conseguem integrar os alunos, fazendo com que eles interajam entre si, e assim irão adquirir uma fluência no idioma, porque eles estarão em comunidade (Maria, intérprete de LIBRAS, 26 anos).

Para Maria, a inclusão se concretizaria com a presença de um professor surdo ministrando aulas para o aluno surdo "tudo que é focado diretamente para eles [os surdos] é muito melhor, porque o nosso trabalho é limitado". Ela destacou que o trabalho do intérprete 
pode ser limitado por questões éticas no momento de interpretar o conteúdo de ciências, que até poderia explicar de outra forma o conteúdo e aí pede auxílio ao professor. Disse-nos também que "não pode ensinar, a gente apenas interpreta, quem ensina é o professor". Nesse ponto entretanto, devemos lembrar que, assim como observado por Pires e Nobre (2004), a informação passada ou transmitida pelo intérprete para o professor, sobre as facilidades e dificuldades do aluno surdo em relação ao modo como a aula está sendo conduzida, é de fundamental importância para o processo de ensino e aprendizagem do surdo. Portanto, de certo modo, o intérprete de LIBRAS está ensinando e colonizando ao mesmo tempo (como afirma Silva Rosa, 2003). Assim, apesar da fala de Maria, discordamos porque o processo de interpretação em LIBRAS promove uma recontextualização do conteúdo e este processo modifica a forma como o conteúdo foi ensinado inicialmente pelo professor de ciências e passa a ser único e singular - não se limita ou se restringe à tradução, especificamente para o surdo, tratando-se sim de um processo de ensino- aprendizagem. Por fim destacamos uma situação mencionada por Lacerda (2010) no Ensino Superior, o surdo "muitas vezes, tem domínio restrito da Libras e menor ainda do léxico da área de conhecimento específico na qual está estudando. Nem tudo que o intérprete traduz em Libras é acessível a ele, gerando problemas no espaço acadêmico" (p. 140).

Quadro 4. Síntese da entrevista com a intérprete de LIBRAS Maria - Parte 2

\begin{tabular}{|c|c|c|c|}
\hline Categoria & Subcategoria & $\begin{array}{l}\text { Unidade de } \\
\text { Registro }\end{array}$ & Unidade de Contexto \\
\hline \multirow{6}{*}{ 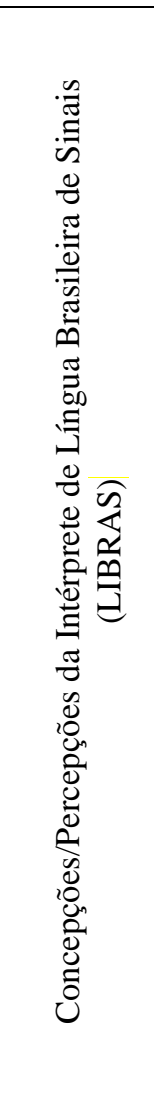 } & \multirow{6}{*}{$\begin{array}{l}\text { Sobre ensinar } \\
\text { ciências para o } \\
\text { surdo }\end{array}$} & $\begin{array}{l}\text { Aulas apenas em } \\
\text { LIBRAS? }\end{array}$ & $\begin{array}{l}\text { [...] seria legal eles terem uma aula dada no idioma deles } e \\
\text { não interpretada por nós, porque tudo que é focado } \\
\text { diretamente para eles é muito melhor. }\end{array}$ \\
\hline & & $\begin{array}{l}\text { Interpretar ou } \\
\text { traduzir? }\end{array}$ & $\begin{array}{l}\text { Porque o nosso trabalho é limitado [...] sabemos que } \\
\text { podemos explicar o conteúdo de outra forma, mas sabemos } \\
\text { que não podemos fazer isso porque o professor não passou } \\
\text { dessa forma, tem a ética. }\end{array}$ \\
\hline & & \multirow[b]{2}{*}{$\begin{array}{l}\text { Investigar o que } \\
\text { o aluno surdo já } \\
\text { sabe }\end{array}$} & $\begin{array}{l}\text { Sim, eu pergunto se eles sabem sobre isso e tal, mas } \\
\text { geralmente eles não conhecem. Porque como eles não têm } \\
\text { essa sensibilidade na comunicação para pesquisar na } \\
\text { internet. Porque não entendem o português. Então, é bem } \\
\text { difícil eles saberem o conteúdo com antecedência, a não ser } \\
\text { que eles tenham uma família que sabe LIBRAS. }\end{array}$ \\
\hline & & & $\begin{array}{l}\text { [...] se eles já sabem e se tem a noção de alguma coisa fica } \\
\text { bem mais fácil [...] a gente precisa saber se eles sabem } \\
\text { aquele sinal específico, por exemplo, sinal de célula, de } \\
\text { bactérias, precisamos saber se eles sabem o que é, se vocêe } \\
\text { apenas traduzir, eles não irão aprender. Se caso eles não } \\
\text { sabem tentamos explicar de uma forma que ele consiga } \\
\text { entender, ou então chamamos o professor para mostrar um } \\
\text { recurso visual. }\end{array}$ \\
\hline & & \multirow{2}{*}{$\begin{array}{l}\text { Ausência de } \\
\text { sinais ou } \\
\text { classificadores }\end{array}$} & $\begin{array}{l}\text { [...] Às vezes, alguns termos, nós temos que pesquisar } \\
\text { sinais que desconhecemos, mas pesquisamos na internet, } \\
\text { buscamos recursos visuais. }\end{array}$ \\
\hline & & & $\begin{array}{l}\text { Mostro recurso visual, depois pesquiso mostro o sinal [...] } \\
\text { Sempre uso recurso visual, e se ele tem internet na casa eu } \\
\text { passo a palavra pra ele pesquisar, passo o site, e no outro }\end{array}$ \\
\hline
\end{tabular}


Ensino, Saúde e Ambiente - V13 (2), pp. 62-89, AG0.2020

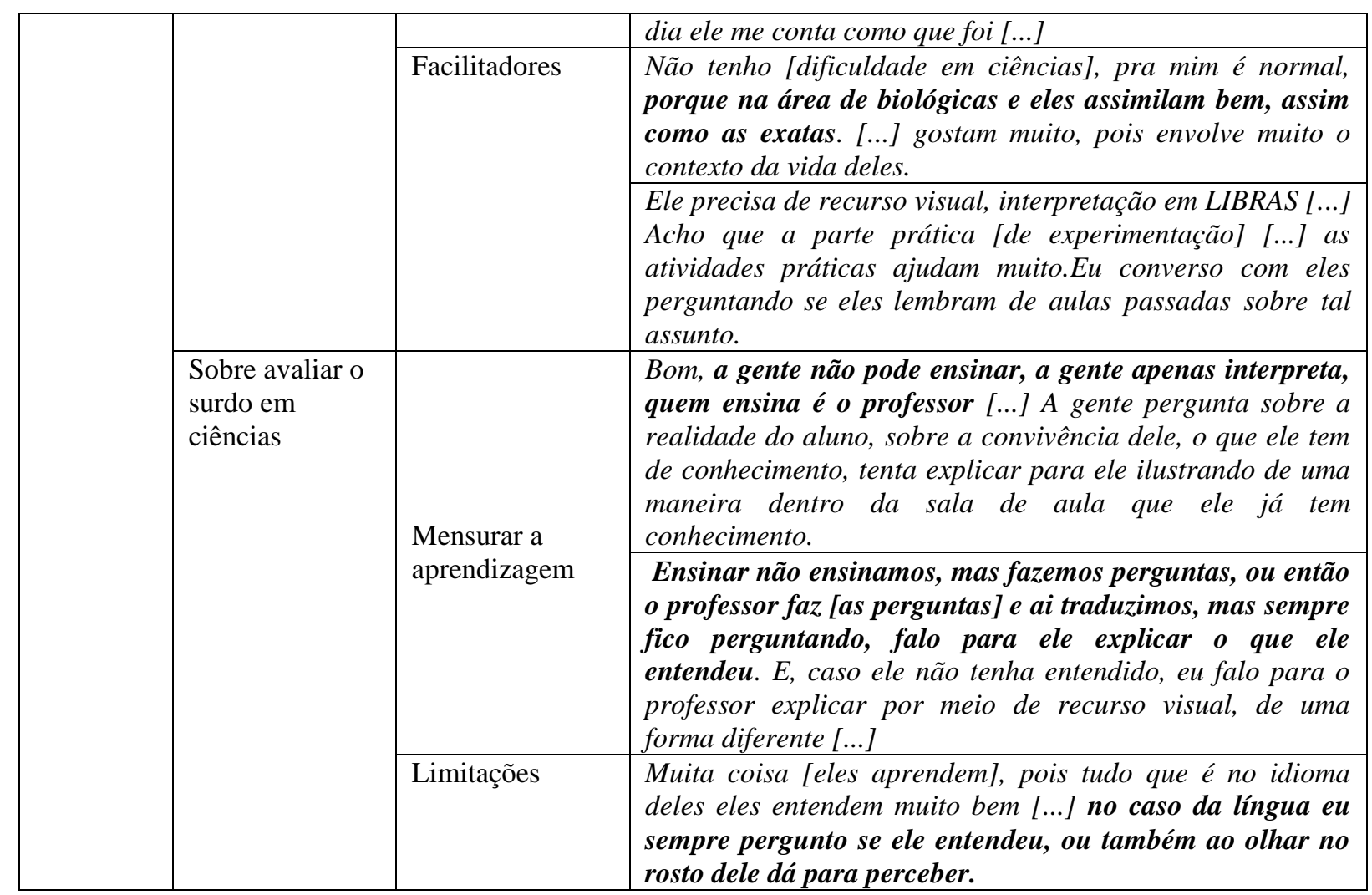

Maria vê importância em perguntar em LIBRAS ao aluno surdo se ele teve contato com o conteúdo que está sendo ensinado e possibilitar que o aluno faça relações com o que o professor está ministrando em ciências. Ela busca em sítios da internet imagens e vídeos para poder facilitar a compreensão dos conteúdos, mas, ela acredita que "a prática é importante", a aula prática e a experimentação em ciências. Na ausência de um dado classificador, Maria disse que a contextualização com o que o surdo já conhece e sabe é fundamental para a compreensão, além do auxílio do professor e dos recursos visuais. Estes dados são consistentes com os encontrados por Gomes e Basso (2014) que investigaram licenciandas que estavam cursando a disciplina de LIBRAS em sua graduação.

Maria destacou que, "às vezes", a professora de ciências avisa antes qual é o conteúdo da aula ou então “eu vejo no livro qual será o próximo conteúdo". Estas duas falas sincronizam o não planejamento conjunto das aulas entre a intérprete e o professor de ciências, prejudicando, como já comentado, o trabalho da intérprete de LIBRAS. Ao mesmo tempo, o professor "segue" sequencialmente o livro didático como rotina de aula e, por fim, que o professor de biologia e ciências tem aulas em muitas outras escolas e um planejamento conjunto "é muito difícil" de ocorrer.

Quando o tema é a avaliação da aprendizagem, Maria pautou-se em medidas subjetivas da aprendizagem do surdo: "No caso da língua [portuguesa], eu sempre pergunto se ele entendeu, ou também ao olhar no rosto dele dá para perceber”. Existem limitações porque o aluno surdo não faz prova dissertativa "é complicado passar a resposta dele em 
LIBRAS para o português" ou faz prova de múltipla escolha.

Ao final da entrevista, Maria assim sintetizou:

[...] A questão ética não me deixa falar muito. Mas em minha opinião é que todos os alunos surdos deveriam conviver numa escola só, para eles aprenderem de uma maneira muito melhor, contudo vem o contexto de inclusão, mas eles deveriam ter um professor surdo, pois a escola regular é muito defasada em relação a ensiná-lo, porque ela é muito voltada ao aluno sem deficiência, e isso prejudica demais a maneira de ensiná-los (Maria, intérprete de LIBRAS, 28 anos).

Em relação a fala de Maria sobre a escola dita especifica (especial), precisamos fazer algumas considerações, primeiramente, ao destinarmos a PcD (com algumas características em comum) para um único tipo de instituição, estamos de fato, segregando esses estudantes a um espaço que muitas vezes é conformista em relação a suas capacidades - como já comentado por Orrú (2016). Não queremos com isso dizer que as escolas de Educação Especial devem ser extintas, mas, nos apropriando das palavras de Carvalho (2005, p.17, grifos nossos): “[...] defendo a educação inclusiva sem que isso seja sinônimo do desmonte da Educação Especial, o que, igualmente, não significa mantê-la inalterada". O que fica evidente na fala de Maria, apesar de suas crenças (sobre o surdo, sobre a inclusão, sobre a comunicação com surdos, sobre o ensino, a aprendizagem e a avaliação do surdo, entre outras), é evidente a sua expertise enquanto profissional intérprete de LIBRAS. Apesar disso, ela não reconhece a possibilidade de emancipação do surdo para o exercício da sua cidadania. Por fim, a intérprete Maria sintetizou assim como os surdos são avaliados em ciências:

As provas funcionam assim: geralmente é de múltipla escolha porque assim não interferimos de maneira nenhuma na resposta dele, porque prova dissertativa é complicado passar a resposta deles em LIBRAS para o português, porque geralmente eles não têm autonomia para responder sozinhos, então temos muita dificuldade para traduzir as palavras deles e então transcrevê-las, então as avaliações são orais e então vamos traduzindo para o professor ou então são de múltipla escolha (Maria, intérprete de LIBRAS, 26 anos).

\section{CONSIDERAÇÕES FINAIS}

A Educação Brasileira passa por profundas e marcantes transformações quando se trata da questão da inserção do estudante surdo em salas de aulas regulares (MANTOAN, 2015), tratam-se de mudanças paradigmáticas que vão além dos aspectos legais e resolvidos por Decretos. São alterações do papel da escola, da função da escola perante a sociedade, dos processos de ensinar-e-aprender, dos aspectos formativos de longo prazo dos quais a escola é a principal responsável.

Sabe-se que a simples permanência do intérprete de LIBRAS não garante ou 
tampouco assegura que questões metodológicas sejam modificadas com a finalidade de adequar-se às necessidades reais do surdo. A falta de uma formação específica do intérprete de LIBRAS pode promover uma visão equivocada de que ele deve ser um generalista e que, por vezes, responsabiliza-se pelos processos de aprendizagem do surdo. Trata-se de ideia que gera uma insatisfatória aquisição de conteúdos do currículo e que cria novos obstáculos ao desenvolvimento do surdo (LACERDA, 2010). Ela salientou que "Muitas vezes, a presença do intérprete acaba por mascarar uma inclusão que exclui" (idem, p.145).

O reconhecimento e a prática de uma formação bicultural e bilíngue de estudantes surdos exige o comprometimento, o envolvimento dos profissionais e da comunidade escolar no sentido de compreender que a língua e a cultura surda não se restringem a meros mecanismos de inclusão do surdo, mas constituem-se na identidade surda (SILVA et al, 2018). Assim, as discussões a respeito do processo de inclusão dos alunos com deficiência(s) - ou para usar uma nomenclatura recente: pessoa com deficiência $(\mathrm{PcD})$ - precisam continuar acontecendo, pois, como pudemos perceber, mesmo professores que fazem parte da Educação Especial possuem equívocos sobre o que é, como se dá, e para quem é destinado o processo de inclusão escolar.

Vale salientar que parte da mudança envolve aspectos formativos dos profissionais (professores, diretores, coordenadores, vice-diretores, intérprete de LIBRAS, bibliotecários, etc.) e demais atores escolares envolvidos num processo que precisa ser mais bem compreendido e estudado, no sentido apontado por Dorziat (2004). As escolas necessitam de maciços recursos e investimento real nos profissionais que ali atuam, não apenas restritos a salários dignos que permitam que eles dediquem-se exclusivamente à escola e aos alunos dos quais eles são responsáveis, mas também voltados à inclusão real destes alunos, nos processos que busquem aproximar Universidade e Escola Pública. Neste artigo buscamos investigar o cumprimento do Decreto $\mathrm{n}^{\circ}$ 5.626/2005 sobre a inserção de intérpretes de Língua Brasileira de Sinais em turmas com alunos surdos e as percepções de intérpretes de LIBRAS sobre o ensino de ciências e biologia para estes alunos. Apesar das garantias legais, percebemos as fragilidades - a lei não garante qualidade ou a adequação do trabalho realizado em sala de aula com o surdo. Como nos lembra Lacerda (2010), a inserção do intérprete de LIBRAS deuse sem o devido cuidado com sua formação prévia, o que levou profissionais sem formação adequada a atuar em diferentes níveis - da Educação Básica ao Ensino Superior. Ao intérprete de LIBRAS, lembra esta autora que ele deve: (a) saber das características de aprendizagem de cada faixa etária, (b) conhecer como são organizados os currículos e (c) as metodologias de ensino mais adequadas a cada nível, (d) compreender as características linguísticas da LIBRAS utilizadas nas diferentes faixas etárias, além de que (e) sua tarefa é atuar em 
ambientes complexos, multideterminados e com muitos interlocutores e inúmeras variáveis (LACERDA, 2010). A respeito do papel (funções) do intérprete de LIBRAS no contexto educacional, pudemos perceber que as duas intérpretes entrevistadas colocavam a "tradução" como única e principal função do intérprete de LIBRAS, fato endossado pela fala de ambas a respeito do papel do intérprete ao dizerem “minha função não é ensinar”. Contradizendo justamente o que é apontado por Lacerda e Poletti:

\begin{abstract}
Em relação ao papel do intérprete em sala de aula, verifica-se que ele assume uma série de funções (ensinar língua de sinais, atender a demandas pessoais do aluno, cuidados com aparelho auditivo, atuar frente ao comportamento do aluno, estabelecer uma posição adequada em sala de aula, atuar como educador frente a dificuldades de aprendizagem do aluno) que o aproximam muito de um educador (2004, p.3, grifos nossos).
\end{abstract}

Assim, acreditamos assim que o trabalho educativo do surdo no contexto do ensino das Ciências Biológicas deva fazer parte das reflexões da formação inicial dos professores desta Área. Do mesmo modo, a especificidade dos processos educativos em Ciências e Biologia deve integrar a formação do intérprete de LIBRAS de modo a fortalecer o compromisso deste educador (do professor regente) com a educação escolar do surdo num contexto inclusivo.

\title{
AGRADECIMENTOS
}

Os autores e autora do trabalho agradecem a colaboração de Igor Zamparo Gomes, Ana Carolina da Silva Barreto, Bianca dos Reis Neves e Laís dos Santos Soares pelas sugestões e cooperação com a realização deste trabalho de pesquisa. Agradecemos ainda ao Conselho Nacional de Desenvolvimento Científico e Tecnológico - CNPq pelo financiamento desta pesquisa pelo Programa Institucional de Bolsas de Iniciação Científica - Ensino Médio (PIBIC-EM).

\section{REFERÊNCIAS}

ANTIA, Shirin D.; KREIMEYER, Kathryn H. The role of interpreters in inclusive classrooms. American Annals of the Deaf, Washington, DC, v. 146, n. 4, p. 355-365, 2001.

ARANHA, Maria Salete Fábio. Paradigmas da relação da sociedade com as pessoas com deficiência. Revista do Ministério Público do Trabalho, Ano XI, no. 21, março, 2001, pp. 160-173.

BARDIN, Laurence. Análise de Conteúdo. São Paulo: Edições 70, 2011.

BRASIL. Lei Federal n. 10.436, de 24 de abril de 2002. Reconhecimento da Língua Brasileira de Sinais e da outras providencias, Brasília, 2002.

BRASIL. Presidência da República. Casa Civil, Subchefia para Assuntos Jurídicos. Decreto N. 5296 de 2 de dezembro de 2004. Brasília. República, Casa Civil, Subchefia para Assuntos 
Jurídicos. Disponível em:

http://www.planalto.gov.br/ccivil_03/_Ato2004-2006/2004/Decreto/D5296.htm Acesso em 25 jul. 2017.

BRASIL. Presidência da República. Casa Civil, Subchefia para Assuntos Jurídicos.

Decreto N. 5626 de 22 de dezembro de 2005. Brasília. Disponível em:

http://www.planalto.gov.br/ccivil_03/_ato2004-2006/2005/decreto/d5626.htm . Acesso em: 25 jul. 2017.

BRASIL. Ministério da Educação. Diretrizes nacionais para a educação especial na Educação Básica. Brasília: MEC/SEESP, 2001.

BRITO, Lucinda Ferreira. Integração social e educação dos surdos. Rio de Janeiro: Babel, 1993.

CAMARGO, Eder Pires de. Inclusão social, educação inclusiva e educação especial: enlaces e desenlaces. Ciênc. educ. (Bauru), Bauru, v. 23, n. 1, p. 1-6, Mar. 2017.

CARNEIRO, Relma Urel Carbone. Educação inclusiva: desafios da construção de um novo paradigma. Em: VIVEIRO, Alessandra Aparecida; BEGO, Amadeo Moura; O ensino de ciências no contexto da educação inclusiva: diferentes matizes de um mesmo desafio. Jundiaí: Paco Editorial, 2015, pp. 31-9.

CARVALHO, Rosita Edler. Educação inclusiva: com os pingos nos “is”, 3 a Edição, Porto Alegre, 2005.

CARVALHO, Anna Maria Pessoa de. (Org.) Ensino de ciências por investigação: condições para implementação em sala de aula, São Paulo: Cengage Learning, 2013.

DORZIAT, Ana. Educação de surdos no ensino regular: inclusão ou segregação? 2004. Em web: https://periodicos.ufsm.br/educacaoespecial/article/view/4921/2955 Acesso em 21.05.2020.

GOMES, Paulo César; BASSO, Sabrina Pereira Soares; O ensino de biologia mediado por LIBRAS: perspectivas de licenciandos em ciências biológicas. Revista Trilhas Pedagógicas. v. 4, n. 4, Ago. 2014, pp. 40-63. Em web:

http://www.fatece.edu.br/arquivos/arquivos\%20revistas/trilhas/volume4/3.pdf Acesso em 21.05.2020.

GOMES, Paulo César; MINGUILI, Maria da Glória; Inclusão escolar na percepção de professores do município de Dois Córregos, São Paulo. Camine: Caminhos da Educação, v. 6, p. 1-29, 2014.

GOMES, Paulo César. FRIGERO, Maria Luisa Passos, Desafios ao ensino de biologia na inclusão do surdo. In: II SIPPEDES - Seminário Internacional de Pesquisa em Políticas Públicas e Desenvolvimento Social, 2016, Franca - SP.

GIL, Antônio Carlos. Métodos e técnicas de pesquisa social. São Paulo: Atlas, 2019.

LACERDA, Cristina Broglia Feitosa de. A inclusão escolar de alunos surdos: o que dizem alunos, professores e intérpretes sobre esta experiência, Cadernos Cedes, Campinas, vol. 26, n. 69, p. 163-184, maio/ago. 2006 Disponível em:

http://www.scielo.br/pdf/ccedes/v26n69/a04v2669 Acesso em 20.05.2020. 
Intérprete de Libras: em atuação na Educação infantil e no ensino fundamental, $7^{\mathrm{a}}$ ed, Porto Alegre: Mediação, 2015.

Tradutores e intérpretes de Língua Brasileira de Sinais: formação e atuação nos espaços educacionais inclusivos. Cadernos de Educação. | Pelotas [36]: 133 - 153, maio/agosto, 2010. Em web:

https://periodicos.ufpel.edu.br/ojs2/index.php/caduc/article/download/1604/1487 Acesso em: 21.05.2020.

. A prática pedagógica mediada (também) pela língua de sinais: trabalhando com sujeitos surdos. Cad. CEDES, Campinas, v. 20, n. 50, p. 70-83, Abril. 2000 . Em web: https://doi.org/10.1590/S0101-32622000000100006 Acesso em: 18.05.2020.

LACERDA, Cristina Broglia Feitosa de; POLETTI, Juliana E. A escola inclusiva para surdos: a situação singular do intérprete de língua de sinais. In: REUNIÃO ANUAL DA ANPED, 27, 2004, Caxambu. Anais... Rio de Janeiro: ANPEd, 2004. Disponível em: http://27reuniao.anped.org.br/gt15/t151.pdf Acesso em: 21 mai. 2020.

LÜDKE, Hermengarda (Menga) Alves; ANDRÉ, Marli Eliza Dalmazo Afonso de; A Pesquisa em educação: abordagens qualitativas. Rio de Janeiro: E.P.U., 2013.

MANTOAN, Maria Teresa Égler. Inclusão escolar: o que é? Por quê? Como fazer? 2.ed, São Paulo: Editora Moderna, 2015.

ORRÚ, Sílvia Ester. Aprendizes com autismo: aprendizagem por eixos de interesse em espaços excludentes. Prefácio de M.T.E. Mantoan. Petrópolis (RJ): Vozes.2016.

. O Re-Inventar da Inclusão: Os desafios da diferença no processo de ensinar e aprender. Prefácio de M.T.E. Mantoan. Petrópolis (RJ): Vozes. 2017.

PAGURA, Reynaldo. A interpretação de conferências: interfaces com a tradução escrita e implicações para a formação de intérpretes e tradutores. DELTA, São Paulo, v. 19, n. spe, p. 209-236, 2003 . Em web: http://dx.doi.org/10.1590/S0102-44502003000300013 Acesso em: 18.Maio.2020.

PIRES, Cleidi Lovatto; NOBRE, Maria Alzira. Uma Investigação sobre o Processo de Interpretação em Língua de Sinais. Em: THOMA, Adriana da Silva; LOPES, Maura Corcini (orgs.) A Invenção da Surdez: cultura, alteridade, identidade e diferença no campo da educação. Santa Cruz do Sul: EDUNISC, 2004, p. 160-188.

POZO, Juan Ignácio; CRESPO, Miguel Ángel Gómez. A aprendizagem e o ensino de ciências: do conhecimento cotidiano ao conhecimento científico. Porto Alegre: Artmed, 2009.

QUADROS, Ronice Müller de. Políticas lingüísticas e educação de surdos em Santa Catarina: espaço de negociações. Cadernos Cedes, 26, 69, 141-161, 2006

RODRIGUES, Cristiane Seimetz; VALENTE, Flávia. Intérprete de libras. Curitiba: IESDE Brasil S.A., 2011. 232 p.

SILVA, Keli Simões Xavier; OLIVEIRA, Ivone Martins de; O Trabalho do Intérprete de Libras na Escola: um estudo de caso. Educação \& Realidade, Porto Alegre, v. 41, n. 3, p. 
695-712, jul./set. 2016. Em web: https://www.scielo.br/pdf/edreal/v41n3/en_2175-6236edreal-41-03-00695.pdf Acesso em 21.05.2020.

SILVA, Carine Mendes da et al. Inclusão Escolar: Concepções dos Profissionais da Escola sobre o Surdo e a Surdez. Psicol. cienc. prof., Brasília, v. 38, n. 3, p. 465-479, Set. 2018.

SILVA ROSA, Andréa. A presença do intérprete de língua de sinais na mediação social entre surdos e ouvintes. Em: RODRIGUES SILVA, Ivani; KAUCHAKJE, Samira; GESUELI, Zilda Maria. (Orgs.), Cidadania, surdez e linguagem: desafios e realidades. Plexus: São Paulo, 2003.

STAKE, Robert E. Pesquisa qualitativa: como as coisas funcionam. Porto Alegre: Penso, 2011.

TRIVELATO, Sílvia Frateschi; SILVA, Rosana Louro Ferreira. Ensino de ciências. São Paulo: Cengage Learning, 2011.

\section{SOBRE OS AUTORES}

AUTOR 1. Possui Doutorado (2010) e Mestrado (2005) pelo PPG Educação para a Ciência, pela Universidade Estadual Paulista "Júlio de Mesquita Filho" - Unesp, Câmpus Bauru - SP. É licenciado em Ciências Biológicas (2002) pela Unesp, Bauru (2002). Atualmente é Professor Assistente Doutor no Departamento de Ciências Humanas, Ciências Nutricionais e da Alimentação, no Instituto de Biociências na Unesp, no Câmpus de Botucatu. Líder do Grupo de Pesquisa Mídia-Educação, Formação de Professores e Ensino de Ciências. Coordenação da pesquisa, redação do texto final do artigo e análise do material.

AUTOR 2. Possui Mestrado (2020) pelo PPG Educação para a Ciência, pela Universidade Estadual Paulista "Júlio de Mesquita Filho" - Unesp, Câmpus Bauru - SP. É bacharel em Física Médica (Unesp, Botucatu, 2017), é licenciado em Física pela FC, Unesp, Bauru. Atualmente é professor da Secretaria de Educação do Estado de São Paulo - SEE/SP. Integrante do Grupo de Pesquisa Mídia-Educação, Formação de Professores e Ensino de Ciências. Redação do texto do artigo, coleta de dados e análise do material.

AUTOR 3. Bolsista do Conselho Nacional de Desenvolvimento Científico e Tecnológico CNPq - Ensino Médio, estudante da Escola Estadual Américo Virgínio dos Santos, SEE/SP, Botucatu - SP. Visita a escolas, agendamento e realização de entrevistas, transcrição e análise parcial do material. 
APENDICE A - Roteiro de Entrevista utilizado neste artigo.

\section{Roteiro de Entrevista - Intérprete de LIBRAS}

(1) O que é a inclusão escolar para você?

(2) O que pensa sobre a inclusão do aluno surdo nas escolas regulares?

(3) Após a regulamentação recente da profissão de intérprete de LIBRAS, profissionalmente ocorreu alguma alteração para você? Explique.

(4) Você gosta de atuar como intérprete? Por quê?

(5) Você possui alunos surdos. Quantos e em que salas eles estão?

(6) Em sua opinião, os alunos surdos são integralmente incluídos nas aulas de ciências (biologia)? Como isso se dá? Explique.

(7) Quais são seus objetivos de ensino para o aluno surdo em ciências (biologia)?

(8) Em sua opinião, o que é mais difícil no trabalho do intérprete de LIBRAS nas aulas de ciências e biologia? Explique.

(9) Ao iniciar um conteúdo é preferível conhecer o que os alunos já sabem sobre ele. Você faz algo para saber se os alunos surdos já conhecem o conteúdo que pretende ensinar? Explique.

(10) Este conhecimento (referente a questão anterior) influencia na maneira como conduz a tradução em LIBRAS dos conteúdos de ciências (biologia)? Explique.

(11) O que faz para contextualizar os conteúdos durante as aulas?

(12) Na ausência de um dado classificador para um conceito ou nome em ciências (biologia), como você age?

(13) Quais estratégias, além da LIBRAS, você utiliza para ensinar os conteúdos de ciências (biologia)?

(14) Você tem facilidade em ensinar ciências (biologia) em LIBRAS? O que, em sua opinião, dificulta o trabalho do intérprete de LIBRAS nestas aulas?

(15) Do que você acha que o aluno surdo precisa para aprender o que você ensina em ciências (biologia)?

(16) Como você avalia se você está ensinando da maneira mais adequada o conteúdo de ciências (biologia)?

(17) O que faz você acreditar que o seu aluno aprendeu o conteúdo previsto?

(18) O que facilita o ensino de ciências (biologia) aos seus alunos surdos?

(19) Quais seriam, em sua opinião, os principais obstáculos para a aprendizagem de ciências (biologia) mediado pela LIBRAS?

(20) E o que facilita, em sua opinião, no ensino de ciência (biologia) mediado por LIBRAS aos alunos surdos?

(21) Como você avalia o aluno surdo nas aulas de ciências (biologia)?

(22) O professor titular auxilia? Como se dá este auxílio?

(23) Existe planejamento conjunto entre você e o professor de ciências (biologia) antes de um conjunto de aulas ser ministrado? Como ele ocorre?

(24) Há algo que gostaria de acrescentar? 